\title{
$\begin{array}{llllll}J & U & R & N & A & L\end{array}$

\section{The Personalistic System of Healthcare in Indonesia: A Case Study}

\author{
http://dx.doi.org/10.25008/jkiski.v5i1.353
}

\author{
Deddy Mulyana ${ }^{1^{*}}$, Dadang Rahmat Hidayat ${ }^{2}$, Susanne Dida ${ }^{3}$, Tine Silvana ${ }^{4}$, \\ Siti Karlinah ${ }^{5}$, Jenny Ratna Suminar ${ }^{6}$, Asep Suryana ${ }^{7}$ \\ ${ }^{1234567}$ Faculty of Communication Sciences - Universitas Padjadjaran \\ Jl. Raya Bandung - Sumedang KM 21, Jatinangor, West Java 45363 - Indonesia \\ *Corresponding author: deddy.mulyana@unpad.ac.id
}

Submitted: 26 March 2020, Revised: 24 May 2020, Accepted: 14 June 2020

Accredited by Kemristekdikti No. 28/E/KPT/2019

\begin{abstract}
The healthcare reality is composed of biomedical, naturalistic, and personalistic systems. Although the three healthcare systems go separately, to some extent they are overlapped. This study aims to explore alternative healing practices in Indonesia based on the personalistic system. The method used is a case study. Data was collected in several big cities (Bandung, Jakarta, Yogyakarta, Surabaya, Palembang, Batam and Makassar) in Indonesia through Focus Group Discussion (FGD) with stakeholders of healthcare programs on media, interviews with physicians, alternative therapists and patients, observation of alternative therapies, and media content analysis. The results indicate that the healthcare practices based on the personalistic system is widespread throughout Indonesia, including religious treatment (often called ruqyah) involving religious chants and prayers. With some using herbal medicine, a lot of alternative therapies based on the personalistic system have been promoted through word of mouth (interpersonal communication) by common people as patients as well as through the electronic media (especially television), and print media (especially newspapers) in many areas in the country.
\end{abstract}

Keywords: Healthcare, Illness, Indonesia, Personalistic system, Social construction.

\section{Introduction}

Healthcare is not universal. As Jonas et al. (in Parker et al., 2009:3) suggest, each society defines healthcare in a rather unique way and develops its diagnostic and treatment theories, practices and tools to serve patients and cure their illnesses. What is defined as illness, what factors cause it and the way to overcome the ailment are affected by the culture of healthcare practitioners and that of the patients. Medical providers who totally adhere to the biomedical (science-based) system of healthcare without realizing the existence of other healthcare systems might underestimate patients' use of religious prayers, traditional healers, herbal medicine, special foods, and other ways of alternative therapies. Waitzkin (2009:116) suggests that any effort by modern medical providers to describe patients' physical ailments may have little or no meaning to a patient from a different culture.

Whether we agree or not, alternative therapists have their own symbolic universe of the ailments and their causes and offer specific solutions which are different and may be contradictory to biomedical solutions. It is in this context that we aim to explore the varieties of alternative healthcare that are widespread in Indonesia, the focus being that based on the personalistic system. In practice this personalistic system is often complemented with herbal medicine (the naturalistic system). Both systems are often termed "complementary and alternative medicine" (CAM), that is, therapies and healing practices beyond the conventional biomedical 
treatment (Ho, 2014: 65; Ho \& Koenig, 2014). Sociolinguistic studies of medical discourse have emphasized the biomedical system of healthcare and have neglected other systems such as complementary and alternative medicine (Kim, 2014). This study is expected to contribute to this scarce discourse.

Indonesia has a population of over 260 million people who live on thousands of islands scattered throughout the archipelago. Some ethnic groups in the country may even have distinct healthcare systems based on their culture which they have inherited from their forebears. The Hindu Balinese in Ubud, for instance, use Ayurveda that originally came from India and emphasizes the use of traditional and naturalistic healthcare to get over various ailments (Putri, 2015), while the villagers in Desa Pasir, Madura, use hot and cold sands by lying or sleeping on the sands to take care of their health (Rachmad \& Surokim, 2015).

Contemporary studies on alternative healthcare practices in Indonesia have been existent, albeit smaller in number than studies on biomedical healthcare practices. To illustrate, Permana (2012) found that the reasons why people seek alternative healthcare include: belief in this form of healthcare, knowledge of the healthcare, and value of the healthcare. More specifically, Yani (2017) studied health communication involving supranatural alternative medicine. She found that the patients suffering from lifethreatening diseases abandoned the biomedical treatment and chose the supranatural medicine because they were disappointed with and were not cured by the expensive biomedical treatment, while they found love, happiness, and meaningful life in the supranatural treatment.

In this paper, instead of exhausting all the alternative healthcare practices found in Indonesia, we will focus on the personalistic system of alternative healthcare practices, including those promoted through media, especially television. Specific cases will be highlighted to get glimpses of the vast number of such alternative therapies throughout the country.

\section{Theoretical Framework}

Healthcare can be categorized into three basic systems (Mullavey-O'Byrne, 1994; Sullivan, 2001): the Biomedical (Scientific) System, the Naturalistic System, and the Personalistic System.

The biomedical system is intertwined in the emergence of natural sciences that can be traced to the Renaissance (Hardey, 1998:5).This is the dominant model of healthcare in the Western world (Berry, 2007:58; Begley \& Ockey, 2012:368). This model has penetrated formal healthcare and healthcare education in Western countries for centuries. It has also penetrated many countries in other continents, including Asia. This model is governed by the following tenets: the separation of mind and body; the machine metaphor for the body, assuming that physicians act like engineers to repair what is dysfunctioning in the body; the merits of technological interventions and the adoption of a technological imperative; the reductionist explanations about the biological changes, ignoring the social and psychological factors; and by placing emphasis on the disease as a phenomena caused by external entities such as parasites, viruses and bacteria (Nettleton, 2006:2). The adherents to the biomedical system assume that an objective reality (disease) exists which is independent from people's attempts to comprehend and control it and apart from their social and psychological factors (Marks et al., 2000:65).

Somewhat overlapped with the biomedical system is the naturalistic system which uses a variety of herbal medicines. This system is used especially in Eastern Asian countries such as China and Korea. In the naturalistic system, the healer examines how the person gets ill and what kind of illness it is. According to this healthcare model, to be healthy the body elements must be in a balanced condition. Therefore, it assumes that illness is caused by the imbalance of these elements in the body, since they are too cold or too hot, experience high emotion or have a poor diet (Sullivan, 2001:374). Natural and environmental forces are also considered factors that make the human system imbalanced.

Based on the naturalistic Chinese perspective, health is seen as the consequence of balance between and within varying entities inside and outside the person. Disease or illness is assumed to be the result of disharmony among all these entities or seen as the result of ordinary activities that have gone wrong, for instance, the effects of climate, fatigue, hunger, wounds or parasites (Porter, 1997:33). The two elements of the human body that need to be in balance are two life forces, Yin and Yang. Yin is the female force often associated with dark, cold and wet, and Yang, the male force often associated with light, hot and dry. So Yin illnesses have to be treated with hot foods such as chicken, while Yang illnesses have to be treated with cold foods such as vegetables, although the terms cold and hot do not refer to the temperature condition (Schiavo, 2007:74).

Like two other healthcare models, the personalistic model can be found in many countries all over the world, especially in underdeveloped and developing countries inhabited by tribal 
groups. Indonesia is no exception. Embedded deep in the Indonesian traditional culture this personalistic system of healthcare maintains that illness is caused by the acts of other human beings or supernatural forces such as witchcraft or sorcery. Health and illness are also often perceived as being the result of unseen intervention of displeased spirits or God. This system often sees the ill person as having committed a sin to other people, animals, or plants. The proponents of this system consider that plants have their own life, knowledge, and wisdom. It is believed that to have sound health, individuals have to be in harmony with the nature. In short, healing is considered to have a spiritual dimension (Renfrey \& Dionne, 2001:349).

While the proponents of the biomedical system adhere to the objective-scientific approach in examining the reality of disease or illness, the healer in the personalistic system seeks to find out who or what caused the ailment to explain why the ailment has occurred and to determine alternative solutions in order to get over the suffering, for example, through rituals, prayers, chants, amulets, etc. The proponents of the personalistic system acknowledge the social construction approach which assumes that illness is best conceived as an intersubjective reality that cannot be examined through positivistic-quantitative approaches. It is difficult to verify such a problem through the traditional way of scientific endeavor since illness is experienced as a complex phenomenon attributed to various meanings, be it physical or psychological, or whether it be individual, social or cultural (Mulyana, 2016:92).

The proponents of the social construction theory, which includes many healthcare providers themselves, assume that individuals with different social and cultural backgrounds may attribute different meanings to the same physical or psychological illness. According to this approach, and regardless of cultural differences, even drugs given to the patient to combat the patient's disease may not only influence the patient's body but also the patient's emotions. Different healthcare providers may use different approaches to the same problem, define similar symptoms differently, and hence propose different solutions. For the proponents of the social construction theory as formulated by Berger and Luckmann (1966) the medical belief systems, like any other belief systems, are systems created through people's interpretations. They are culturally specific, produced and negotiated creatively and designed to overcome particular practical problems (Nettleton, 2006:17). In brief, the biomedical system of healthcare, including its content and practices, no matter how scientific and empirical it is, like the naturalistic system or the personalistic system, is socially constructed.

\section{Material and Methodology}

This study is part of a larger research project which lasted for three years from 2016 to 2019. The whole project involved Focus Group Discussions (FGD) with several types of alternative therapists (energy transfer therapists, massage therapists, herbalists and others), media key persons in charge of media (alternative) healthcare programs which include television programmers, officers of KPID (Provincial Broadcasting Commission), officers of Dinas Kesehatan (Provincial Health Offices, a smaller unit of the Health Ministry), and communication academics (lecturers). We have done this FGD in Bandung in the Province of West Java, Surabaya in the Province of East Java, Palembang in the Province of South Sumatera, Batam in the Province of Riau Islands, and in Makassar in the Province of South Sulawesi. Each FGD lasted for two to four hours.

To comprehend the larger picture of the personalistic system of healthcare practices, we have interviewed dozens of common people as patients, and dozens of physicians (medical specialists and general practitioners) in Jakarta, Bandung, and Yogyakarta. We have also observed and undergone some of those health practices in several research locations. Apart from the fieldwork, we have observed television programs (including those in Youtube) taken from sample areas and contents of the internet; we have used contents of the print media, so far as the materials enriched the study. Past research findings have also been added. So in a way, this study contains some meta-research.

\section{Results and Discussion}

In Indonesia the three systems of healthcare: biomedical, naturalistic, and personalistic can be found throughout the country. The biomedical system is more dominant in big cities and cosmopolitan areas. However, in remote areas naturalistic and personalistic healthcare systems are more commonplace than in cities, although it does not mean that in cities the two systems are much less important than the biomedical system. Indonesia is a good case where people may combine the three systems of healthcare simultaneously. They may go to physicians and take the prescribed medicine when they suffer from headaches, high-blood pressure, cough, heart failure, and even cancer, but they also drink jamu liquid made of herbs at a different time of the day (based on the naturalistic system) and pray to God 
to alleviate their suffering at prayer times (based on the personalistic system).

Many Indonesians seem to follow what most Asians believe to be the nonbiological causes of illness, especially "imbalance" of cold and hot food, lack of harmony with nature, and too many emotions and are less satisfied with the Western healthcare services (Kazarian \& Evans, 2001:406). According to a socio-economic survey in 2004, $72.44 \%$ of the Indonesian population conducted self-treatment and $32.87 \%$ used traditional medicine. At that time there were approximately 280,000 traditional healers who practiced 30 branches of expertise in Indonesia (pusakapusaka.com, 3 April 2019). In another survey, it was found that among $30 \%$ of the Indonesian population who complained that they were ill, $40 \%$ sought alternative healthcare, while $60 \%$ visited hospitals and physicians (republika.co.id, 21 November 2016)

\section{The Superstitious Healthcare}

Part of the personalistic system of healthcare is "superstitious" in nature. In many villages among the widely dispersed islands of Indonesia many people still believe that witchcraft may cause illness and even death. They often think that the sicknesses of babies or children have been caused by evil spirits. To wipe away the illness, families often ask the help of a shaman who believes that this world is not only inhabited by humans but also by spirits that occupy mountains, caves, rocks, rivers, forests, trees, etc. and that these spirits must be appeased in order to cure the illness, and the people believe that it is these spirits that have caused the illness. These traditional spiritual healers may use traditional medicine (herbs), plain water possessing a "magic formula," and/or carry out certain rituals (including chanting). Sometimes the shaman asks the family of the sick person to provide certain animals, for example a white chicken or a black chicken, black goats, eggs, certain kinds of flowers, etc. It is assumed that the shaman can transfer one's ailment to these items.

A common term for a person who is considered to have the capability to cure people by using his or her "healing expertise" is orang pintar (smart person). One of the most popular smart persons is Ponari from Jombang, East Java, especially in the past (2009) when he was still a boy. He has intensively practiced this personalistic system of healthcare for many years by providing water (to be drunk by his patients) from a basket with a stone in it, regardless of the efficacy of the healing process. More recently, another wellknown contemporary orang pintar is Ningsih Tinampi in Karangjati, Pasuruan, East Java. As reported by TV One (3 December 2019), thousands of patients will have been waiting for treatment until the year 2021.In the past, many patients had to wait months to get the treatment. Every day Ningsih has to treat between 60 and 100 patients, each patient having to pay a regular fee of $\mathrm{Rp}$. 300,000 ,-, while each special patient (who does not want to wait long) has to pay Rp. $1,500,000,-$. TV One reported that although many patients came to be treated by Ningsih Tinampi with ailments such as stroke, vertigo, gastric acid, and various kinds of physical pains, many ailments were considered by her as being caused by santet (black magic). That is why the most popular treatment is called Lepas Pocong (Releasing Ghosts) charging a patient Rp. $5,500,000,-$. TVOne reported, the head of the Indonesian Physicians Association of the Pasuruan Regency, Sujarwo argued that in fact many of those patients had to be treated professionally (based on the biomedical system).

In South Sulawesi, these orang pintar (smart persons) include some people suffering from oligodactyly (lobster-claw syndrome) who work as Paraji, that is, traditional healers whose expertise to cure people has been inherited from their parents. These people are considered as having supernatural powers enabling them to give favors to the environment, for example, by leading the ritual Mappare lise tasi ritual in the Village of Ulutaue. In this ritual people feed the spirit of the sea by bringing tuli (food) composed of colorful rice, eggs, banana leaves as the cover of the food, sirih leaves and some money folded with the sirih leaves. Through this ritual, it is expected that the fishermen will be given safety and much sustenance by the 'sea guard' named pajjagatasi (Mulyana \& Sulaeman, 2016).

Based on our interviews with dozens of patients and physicians, we have found that some patients visiting these physicians believe in unscientific and even superstitious causes of illness. For instance, in one case, a dentist recommended that a patient's tooth be pulled out, but the patient was worried and refused the dentist's recommendation because the patient believed a myth that the patient would go blind. In another case, an orthodontist asked her assistant to provide tea to a fainted patient. The assistant said that it could not be done as tea was prohibited according to the patient's belief as a Seven-Day Adventist. Still another interesting case is where a patient did not produce a lot of breast milk because she was always exhausted. When the doctor told her to sleep more, especially during the day time, the patient did not do it because she believed that if a woman who had just given birth to a baby slept 
in the middle of the day she would get worms inside her body.

\section{The Islamic Way of Healing}

Many hospitals in Indonesia, especially those affiliated with religious organizations (particularly Christianity and Islam) also believe in the personalistic system by utilizing the intervention of clergy to motivate patients to observe more religious prayers and by providing patients with holy books to read so that the spiritual enlightenment gained by the patients will make their recovery faster. Many hospitals affiliated with different religions provide holy books in the patient rooms, for instance in Catholic hospitals such St. Carolus Hospital in Jakarta and Borromeus Hospital in Bandung and Islamic hospitals such as Islamic Hospital Cempaka Putih in Jakarta and the Al Islam Hospital in Bandung.

Islamic healing can be considered as a distinct subculture in Indonesia whose major population are Muslims. This healthcare system is often referred to as Thibun Nabawi, meaning the healthcare system of the Prophet (Muhammad, Peace be Upon Him). According to Usman et al. (2018), therapeutic communication in the treatment of Thibbun Nabawi is derived from the concept of holistic Islamic health, which purports to help the cure process of the patient's illness as well as to strengthen his or her mental and spiritual power. Because of this, Usman et al. (2018) suggest that the therapist's religiosity plays an important role in the healthcare. This religiosity is embedded in the therapist's personality resulting from a long process in the life of the therapist which can be reflected in verbal and nonverbal messages conveyed by the therapist; the therapist believes that it is God who is the healer, while he or she considers himself or herself as a mediator who must be patient and hopeful to get blessings from God Almighty.

Ruqyah (healing treatment through religious chanting) and hijamah or bekam (cupping therapy) are instances of the Islamic healing which are considered to have been derived from the Prophet Muhamad's tradition. Honey, dates, olive oil, and habbatus sauda (seeds of Nigella Sativa) are natural medicine often recommended in the Islamic healing. As Jamil (2014:758) suggests, although there are differences in the practices of the Islamic healing among therapists, common types include prayers, reciting the Qur'an, zikr (chanting) and contemplation. Since Indonesia is inhabited by a Muslim majority, many clinics and/or stores in big cities throughout the country offer healthcare services based on the Islamic tradition. One of these clinics which has dozens of branches throughout Indonesia is Bekam and Ruqyah Center (BRC).

There are two main instances of Islamic rituals that can be explained through the three healthcare systems logically, namely prayers and fasting. Proponents of all three systems agree, and even based on the results of medical examinations that people who observe prayers and fasting consistently are more likely to be healthier than those who do not. Soleh (2001) elaborated the favorable effects of midnight prayers (tahajjud) on Muslims' health based on medical parameters. According to his book, which is based on his doctoral dissertation at Airlangga University which he finished in the year 2000, the night prayers improved the bodily immunity of the actors and their ability to cope with stress.

Some contemporary Islamic healing practices have been inserted into hypnotherapy practices, not only attended by people in prepaid direct sessions, but also in hypnotherapy practices inserted into Islamic religious programs, such as "Islam itu Indah" (Islam is Beautiful) on Trans TV. In one hypnotherapy workshop attended by one researcher in Bandung, a trainer taught selfhypnosis by tapping meridian points in the body (top of head, forehead, chin below lower lip, among others) with fingers many times while he kept saying, "O, Allah, although I have been suffering from a migraine (or any other ailment), I sincerely accept this ailment."

Some physicians, whom we interviewed, believe that in addition to the power of prayers to overcome illness, sins could cause illness. In an interview, a religious medical specialist related that he found a female patient who complained about her illness, but the medical laboratory showed no clear evidence. When asked if she had a personal secret, the woman admitted that as a gold seller, she often cheated by reducing the weight of gold she sold. "That what makes you ill," said the medical practitioner. This incidence explains that one's anxiety emerging from cheating can lead to his or her illness.

\section{The Alternative Therapy and Its Promotion}

In the provincial capital cities of Indonesia where the population is dense, alternative healthcare practices have been promoted through public and private television programs (including pay television), radio programs, and local newspapers. There is no less promotion in the internet (especially Youtube) and through billboards, plates and signs set in front of the therapy clinics in many cities. Many small and simple abodes are places used to offer alternative healthcare to those in need. 
In addition to the central and regional public television stations (TVRI), there are hundreds of private television stations (including pay TV stations) in all 34 provinces in Indonesia. Many of them have promoted CAM and alternative healthcare practices. In 2014 the number of all TV stations was 394, and over 400 in 2018. While the national public television station (TVRI) broadcasts nationally, apart from 14 private commercial television stations with national coverage, and dozens of pay private TV stations, each province has its own provincial public television station (TVRI) and private local television stations.

A common way of broadcast is through timeblocking or semi time-blocking. In a way it is like buying a segment of time (30 minutes to one hour) per program. The therapists may use this segment of time a few times a week. They may also use sponsors to contribute to the cost of the program. A standard program is a talk show involving the conversation between media presenters and therapists. While the therapy practices are shown on these programs, testimonies are given by former patients who have recovered from their illnesses. Some interactive consultations between therapists and television audiences are also possible. In some cases the therapists advertise their services through running texts on different programs which cost cheaper.

In the Hitam Putih (Black White) Program on Trans 7, guided by Deddy Corbuzier (a popular male presenter who used to be a prominent magician), there was a portrayal of a therapist named Pak Masudin who was able to cure a deaf boy in 30 seconds by "pressing and opening" the auditory nerves in the head of the boy. This treatment is clearly based on the personalistic system. In another case, guided by a popular female physician who is also a celebrity, ANTV once broadcast a healthcare program about an alternative therapist who was able to transfer a disease from a person's body to a chicken. In another program guided by another female presenter, when answering the question of one member of the TV audience, a healer named Asari advised that those who have low sexual libido should avoid fornication or adultery. Most recently (28 April 2019) through MNC Television the spiritual healer Ustadz Dhanu emphasized that prayers had to be observed by a woman named Hilda Marhenda who was suffering from kidney problems, migraine, and whose ovarium had been operated due to her past sins to her parents. "The spirits had a kingdom in her head and her stomach that causes her illness," said Ustadz Dhanu, the spiritual healer while Hilda was also present among the audience in the TV studio.

In Palembang, the alternative therapist often promoted by PAL TV is Jeng Jumaroh who was an expert in herbal medicine to cure ailments with the basic concept "Back to Nature." In addition to television, the herbalist Jeng Jumaroh has also used internet (web) to promote and sell the naturalistic medicine. Through her service on this private television, Jeng Jumaroh intends to enhance holistic health, not only physically but also by promoting positive thinking and a healthy diet. According to her, until recently she had 11,000 listed patients, but now there could be more patients, including those not listed. Broadcasting once a week, Jeng Jumaroh used consultation (questions and answers) in her weekly PAL TV program. Commenting on her herbal medicine, Jeng Jumaroh said, "The Tempuyung leaves have benefits. Just try. A person suffering from fever does not always need antibiotics but can use Cakar Ayam leaves ... Essentially, I want to say that the medicinal plants we have inherited from our ancestors are very beneficial". She believed that based on her knowledge, she just tried the best she could to cure people. According to her, recovery belongs to God. Jeng Jumaroh's opinion is in parallel with the views of many medical doctors and orang pintar that whether people recover or not from their ailments depends on God. This again implies that many therapists in Indonesia, regardless of the system of healthcare they embrace, to some extent believe in the personalistic system of healthcare involving health recovery as God's grace.

In Surabaya, East Java, one alternative therapist is Gito who provides his own style of healthcare services. Gito is better known as Ali in the alternative healthcare arena. He has been involved in alternative healthcare since the year 2000. His expertise constitutes multitherapy, including energy transfer, nerve tapping and acupressure. Gito explained that the basic idea is the activation of all the body's organs. He said that he is also able to repair the broken bones. "My diagnosis is not similar to a physician's diagnosis. I do it with my soul and can detect the nerves and muscles in the human body because God has created such organs with their signals that can be learned and detected. The accuracy is quite good, close to $80 \%$ or $90 \%$." Gito claimed that besides giving a treatment he also used herbal medicine produced by a company that has become his partner in the healthcare. Having known that promoting alternative healthcare through brochures was a failure, Gito utilized several television stations in East Java. The TV program 
was usually interactive in nature. He has mastered the alternative skills through self-learning, that is by learning the legacy handed down from his ancestors. His first live television program was in fact on Jak TV in Jakarta, then he turned to TV Banten, and then to MNC TV.

Meanwhile, in Makassar, South Sulawesi a TV station that regularly broadcasts alternative healthcare is Celebes TV. Named Talk Healthy, the program is broadcast every Saturday from 09.00 to 10.00 AM. The form of program is usually a discussion (talkshow) sponsored by product companies. However, Celebes TV also broadcasts other alternative healthcare programs lasting for 30 minutes through time-blocking. These programs offer products and haelthcare services. The types of alternative therapy desired by the public at the time of the FGD were Terapi Garang Arang, Ratu Givana, Sinshe Mayang, and Jacket Warsito. Our FGD with the informants in Makassar indicated that many people who suffered from cancer did not want to visit physicians, as they were scared to do so. Instead, they went to see shamans or they used herbal medicine based on the information they knew through word of mouth or media advertisements or commercials. Another reason why they preferred to go to alternative healers is that it cost cheaper than to go to medical doctors. However, when they failed to cure their ailment, they finally visited medical doctors but by then it was often too late so that some of them passed away.

CAM is often promoted in media all over Indonesia, not only through electronic media but also print media, especially local newspapers. In Palembang such local print media include Tribun, Sriwijaya Post, and Sumatera Expres; in Surabaya, Duta Masyarakat and Harian Surya. Of all the kinds of therapies advertised in the electronic media, the internet, billboards, plates, local newspapers, and even through word of mouth, therapies to overcome sexual impotence and to enhance sexual libido are commonplace. In West Java and Jakarta, among well-known therapists who have claimed to be able to boost sexual libido was an old woman named Mak Erot whose career has since been continued by her grandchildren. Mak Erot is now like a brand. Those not related to Mak Erot and her family also offer similar Mak Erot treatment: massage, herbal medicine, and chants. The service cost is often called mahar which literally means dowry.

Treatments to enhance sexual libido have also been advertised by some local private TV stations in various provinces, such as by one TV station in Palembang. It normally broadcast after $10 \mathrm{PM}$ as the target was adults. Local and provincial newspapers also have a lot of advertisements, such as the provincial daily newspaper Tribun Jabar published in Bandung, West Java. In its edition (December 24, 2017), for example, all of five advertisements offered such treatment. One mentioned that it had a permit from Dinas Kesehatan (The Regional Department of Health). All advertisements mention the mahar, respectively 200 thousand, 300 thousand, 400 thousand rupiahs (ranging from 14 to 30 USD). There is a statement under the advertisements that the content of the advertisement material is fully the responsibility of the advertisers.

\section{Conclusion}

There is a variety of healthcare services in Indonesia. The three healthcare systems delineated so far (the biomedical, the naturalistic, and the personalistic) are not mutually exclusive; rather, they are complementary to each other.

In Indonesia the nonbiomedical system (naturalistic system combined with the personalistic system) of healthcare is dominant and commonplace apart from the biomedical system. These alternative healthcare practices can be found in many big cities as well as in small towns all over the country. This follows the trends that are also found in most countries all over the world. Even some medical practitioners who embrace the biomedical system have also used the personalistic system by saying that medical recovery is the grace from God. The personalistic system of healthcare in particular has been intensively practiced by orang pintar (smart persons). It has also been broadcast on electronic media, especially television, in addition to its publication and advertisements in the print media and the internet.

As far as electronic media is concerned, there has not been a uniform application of the media regulations for the advertisements and the portrayals of the alternative healthcare practices on the media, including those based on the personalistic system. In addition, there has not been solid coordination and supervision among authoritative institutions for these alternative healthcare programs on media, whereas some of the programs might harm audiences or even deceive them. Such institutional cooperation, especially in the form of joint regulations, is deemed necessary to prevent harmful impact on the audiences.

\section{Acknowledgement}

This research has been funded by ALG (Academic Leadership Grant) Universitas Padjadjaran, Indonesia 


\section{References}

Begley, P. A. \& Ockey, D.A. (2012). Health Jouneys: Intersections between Ancient Healing and Modern Medicine. In Larry A. Samovar, L.A., Porter, R.L. \& McDaniel, E.R., eds. Intercultural Communication: A Reader. International Edition. Australia; Wadsworth, 366-380.

Berger, P. L. \& Luckmann, T. (1966). The Social Construction of Reality. New York: Double Day.

Berry, D. (2007). Health Communication: Theory and Practice. New York: Open University Press.

Hardey, M. (1998). The Social Context of Health. Buckingham: Open University Press.

Ho, E.Y. (2014). Alternative and Complementary Medicine. In Thompson, T.L., ed. Encyclopedia of Health Communication. Los Angeles: Sage, 65-70.

Ho, E.Y. \& Koenig, C.J. (2014). Provider-Patient Communication about Complementary and Alternative Medicine. In Hamilton, H.E \& Chou, W.S. The Routledge Handbook of Language and Health Communication. London: Routledge, 506-519.

Jamil, R. (2014). Islamic Healing. In Thompson, T.L., ed. Encyclopedia of Health Communication. Los Angeles: Sage, 758759.

Kazarian, S. S. \& Evans, D.R. (2001). Health Psychology and Culture: Embracing the $21^{\text {st }}$ Century. Handbook of Cultural Health Psychology. San Diego: Academic Press.

Kim, K. (2014). Negotiation of Health, Illness, and Treatment in Korean Oriental Medical Discourse. In Hamilton, H.E \& Chou, W.S. The Routledge Handbook of Language and Health Communication. London: Routledge, 520-538.

Marks, D.F, Murray, M., Evans, B. \& Willig, C. (2000). Health Psychology: Theory, Research and Practice. London: Sage.

Mullavey-O'Byrne, C. (1994). Intercultural Communication for Health Care Professionals. In Brislin, R.W. \& Yoshida, $\mathrm{T}$., eds. Improving Intercultural Interactions: Modules for Cross-Cultural Training Programs. Thousand Oaks: Sage, 171-196.

Mulyana, D. (2016). Health and Therapeutic Communication. Bandung: Rosda.

Mulyana, D. \& Sulaeman. (2016). People with Lobster-Claw Syndrome: A Study of Oligodactyly Sufferers and Their Communication Behaviors with People around Them. Mediterranean Journal of Social Sciences 7 (1), 136-141.

Nettleton, S. (2006). The Sociology of Health and Illness. Second Edition. Malden: Polity Press.

Parker, C.P., Woelfel, R.L., Hart, E.S. \& Brown, G. (2009). The Challenge of Healthcare and Disability. In Parker, J.C. \& Thorson, E., eds. Health Communication in the New Media Landscape. New York: Springer, 3-21.

Permana, M. (2012). Penggunaan Pengobatan Alternatif dalam Proses Penyembuhan Penyakit: Studi Pengguna Pengobatan Alternatif di Bogor. Unpublished Thesis. Faculty of the Social and Political Sciences, the University of Indonesia.

Porter, R. (1997). The Greatest Benefit to Mankind: A Medical History of Humanity from Antiquity to the Present. London: HarperCollins.

Putri, I.D.A.H. (2015). Komunikasi Terapeutik dalam Terapi Pengobatan Ayurveda di Ubud Bali. Paper Presented in Health Communication Symposium in the Faculty of Communication Sciences, Padjadjaran University, Indonesia, September 16, 2015.

Rachmad, T.H. \& Surokim (2015). Gaya Hidup Masyarakat Sumenep Madura Melalui Media Pasir dalam Kajian Komunikasi Kesehatan. Paper Presented in Health Communication Symposium in the Faculty of Communication Sciences Padjadjaran University Indonesia, September 16, 2015.

Renfrey, G.S. \& Dionne, R.R. (2001). Health Psychology and the Native North American Client. In Kazarian, S.S. \& Evans,D.R., eds. Handbook of Cultural Health Psychology. San Diego: Academic Press, 343-385.

Schiavo, R. (2007). Health Communication: From Theory to Practice. San Francisco: JosseyBass.

Sullivan, T.J. (2001). Sociology: Concepts and Applications in a Diverse World. Fifth Edition. Boston: Allyn \& Bacon.

Usman, T.R.S., Mulyana, D., Hadisiwi, P. \& Perbawasari, S. (2018). "Religiosity in Therapeutic Communication of Islamic Medicine Thibbun Nabawi." Atlantis Press: Proceedings of the International Conference on Business, Economic, Social Science and Humanities (ICOBEST 2018)

Waitzkin, H. (2009). Culture, Communication, and Somatization in Health Care. In D.E. Brashers \& D.J. Goldsmith, eds. Communicating to Manage Health and Illness. New York: Routledge, 113-134. 
Yani, W.O.N. (2017). Komunikasi Kesehatan dalam Pengobatan Alternative Supranatural: Studi Fenomenologi tentang Pasien yang Berobat pada Pengobatan Alternatif Supranatural. Unpublished Dissertation. Faculty of Communication Sciences Padjadjaran University. 